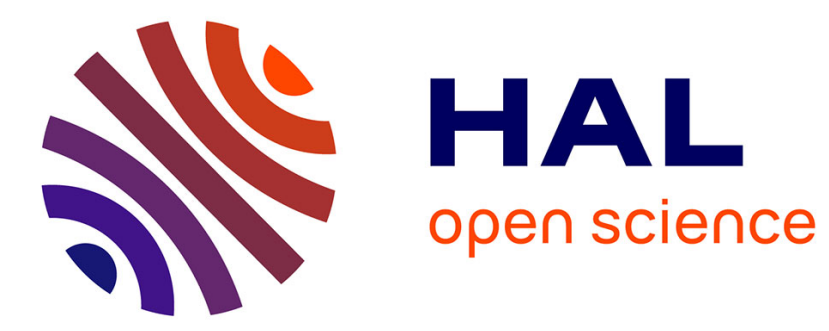

\title{
Influence of porosity on lipid preservation in the wall of archaeological pottery
}

Léa Drieu, Matthieu Horgnies, Didier Binder, Pierre Petrequin, Anne-Marie Pétrequin, Kewin Peche-Quilichini, T. Lachenal, Martine Regert

\section{- To cite this version:}

Léa Drieu, Matthieu Horgnies, Didier Binder, Pierre Petrequin, Anne-Marie Pétrequin, et al.. Influence of porosity on lipid preservation in the wall of archaeological pottery. Archaeometry, 2019, 61 (5), pp.1081-1096. 10.1111/arcm.12479 . hal-02371740

\section{HAL Id: hal-02371740 \\ https://hal.science/hal-02371740}

Submitted on 3 Dec 2021

HAL is a multi-disciplinary open access archive for the deposit and dissemination of scientific research documents, whether they are published or not. The documents may come from teaching and research institutions in France or abroad, or from public or private research centers.
L'archive ouverte pluridisciplinaire HAL, est destinée au dépôt et à la diffusion de documents scientifiques de niveau recherche, publiés ou non, émanant des établissements d'enseignement et de recherche français ou étrangers, des laboratoires publics ou privés. 
Léa Drieu ${ }^{\mathrm{a},{ }^{*}, 1}$, Matthieu Horgnies ${ }^{\mathrm{b}}$, Didier Binder ${ }^{\mathrm{a}}$, Pierre Pétrequinc ${ }^{c}$, Anne-Marie Pétrequin ${ }^{c}$, Kewin Peche-Quilichini $^{\mathrm{d}, \mathrm{e}}$, Thibault Lachenal ${ }^{\mathrm{e}}$, Martine Regert ${ }^{\mathrm{a}}$

a CNRS, Université Côte d'Azur, CEPAM, France

${ }^{\mathrm{b}}$ LafargeHolcim R\&D, 95 rue du Montmurier, 38291 Saint Quentin Fallavier, France

' Maison des Sciences de I'Homme et de l'Environnement C.N. Ledoux, CNRS \& Université de Franche-Comté, 32 rue Mégevand, 25030 Besançon Cedex, France

d Inrap Méditerranée, France

e ASM, UMR5140, Univ Montpellier 3, CNRS, MCC, France

* Corresponding author. E-mail address: lea.drieu@york.ac.uk (L. Drieu)

${ }^{1}$ Present address: BioArCh, Department of Archaeology, University of York, Wentworth Way, Heslington, York, YO10 5NG, United Kingdom.

\section{ABSTRACT}

Porosity of archaeological pottery is a key parameter to assess its ability to trap lipids during the use of the pot and to preserve them overtime. Mercury intrusion porosimetry and gas chromatography were used to study the distribution of porosity and the preservation of lipids in different chronocultural contexts. The data obtained show that the porosity pattern, related to the raw materials and the savoir-faire of the potters, influences the amount of lipids accumulated in the pottery. A significant overall porosity together with high level of small pores is generally favourable to the preservation of lipids, but variations related to the environmental context are observed.

\section{KEYWORDS}

Organic residue analysis; Mercury intrusion porosimetry; Organic matter degradation; Pottery use

\section{INTRODUCTION}

Organic molecules have proven to be absorbed inside the walls of unglazed pottery during their use and to be preserved over millennia in archaeological vessels (Charters et al., 1997; Evershed, 2008; Evershed et al., 1995; Regert, 2011). Thanks to the development of analytical techniques such as gas chromatography, mass spectrometry and isotopic ratio mass spectrometry, a wide diversity of 
natural substances was detected in archaeological pottery. The study of these organic residues provided valuable data to understand past communities and their changes over time by investigating pottery function (Drieu et al., 2018; Fanti et al., 2018; Salque et al., 2013) and the exploitation of natural resources (e.g. Craig et al., 2011; Debono Spiteri et al., 2016; Evershed et al., 2008b).

The porous nature of unglazed ceramics is known to be one of the key parameters allowing both absorption and preservation of organic products inside pottery walls (Evershed et al., 2008a; Shepard, 1956, p. 126). The absorption of liquid or semi-liquid substances inside the pores of unglazed pottery is easily understood, and the analysis of non-porous vessels generally yields poor results (Evershed, 2008), except if micro-cracks exist on pottery surface (Pecci et al., 2015, 2016). The absorption of organic molecules inside the porous ceramic matrix is thought to be an essential factor of their preservation over time (Eglinton et al., 1991; Heron and Evershed, 1993). Indeed, when trapped into the pores, the organic molecules are protected from the surrounding sediment, in an environment generally less favourable to the growth of microorganisms ( $\mathrm{pH}$ conditions, availability of oxygen, water, and nutriments; Aillaud, 2001, pp. 4-5; Evershed, 1993, 2008). Furthermore, part of the organic compounds is located in small-size pores that strongly limit their access for fungi and microorganisms (Evershed, 1993, 2008; Heron et al., 1991; Heron and Evershed, 1993). Thus, porosity characteristics are thought to play an important role in both the absorption and preservation of organic molecules within the pottery walls.

Porosity of ceramic vessels has been investigated for studying pottery manufacture and firing (Carvalho et al., 2006; Gomart et al., 2017; Maniatis and Tsirtsoni, 2002; Morariu et al., 1977; Sanders, 1973; Sobott et al., 2014; Thér, 2016; Volzone and Zagorodny, 2014), physical properties related to pottery function (Lapp, 2012; Moraru and Szendrei, 2010; Rice, 1987, pp. 350-354), and resistance to degradation during burial (Bronitsky, 1986, pp. 225-231). However, although several authors mention relationships between porosity and organic products trapped into pottery walls, only few have investigated porosity in this view (Correa-Ascencio and Evershed, 2013; Matlova et al., 2017; Namdar et al., 2009) and none have specifically studied the properties of absorption and preservation of organic molecules detected in archaeological pottery using porosity analysis. From a methodological perspective, porosity of archaeological pottery has been studied by producing 2D images using Scanning Electron Microscope (SEM; Carvalho et al., 2006; Correa-Ascencio and Evershed, 2013; Maniatis and Tsirtsoni, 2002; Moraru and Szendrei, 2010) or 3D images by micro tomography (Gomart et al., 2017; Kulkova and Kulkov, 2016; Sobott et al., 2014). Both techniques have the advantage of being non-destructive, but quantitative study of the distribution of porosity requires specific data processing (image analysing software or mathematical treatments of the tomography data; Adrian De la Fuente and Vera, 2015; Aprile et al., 2014; Reedy et al., 2014, Thér, 2016). Mercury Intrusion Porosimetry (MIP), a technique specifically adapted to the quantitation of the porosity that allows both the measurement of the total volume of pores and an estimation of the pores distribution depending on their diameter (Giesche, 2006; Sobott et al., 2014), was used to study the porosity of archaeological ceramics (Matlova et al., 2017; Morariu et al., 1977; Namdar et al., 2009; Sanders, 1973; Sobott et al., 2014; Volzone and Zagorodny, 2014), but up to now, the question of the influence of porosity on the preservation of organic molecules has not yet been considered in this way 
With mercury intrusion porosimetry, the present study investigates the relationship between the amount of lipids preserved in archaeological potsherds and the porosity of the ceramic matrix (quantity of pores and distribution). This issue is addressed by studying the porosity of potsherds taken from three different chrono-cultural contexts and having preserved various quantities of lipids as determined by gas chromatography analysis. By improving our understanding of the impact of porosity on the amount of lipids extracted from archaeological sherds, this work aims, in the long term, to (i) determine if it is possible to build a selection grid for optimising sampling of archaeological pottery for lipid analysis; and (ii) better understand lipid absorption and preservation in pottery walls for in-depth interpretation of pottery use.

\section{MATERIALS AND METHODS}

Archaeological potsherds

Three archaeological sites, having different chronological and geographical locations, were chosen to represent different contexts of preservation which were either more, or less favourable to biochemical (anoxic vs. oxic conditions, basic vs. acid sediment) and physical degradation (various degrees of waterflow, wetlands).

The Pendimoun rock shelter was chosen to represent a context favourable to biochemical degradation processes, with oxic conditions of burial and basic sediments related to the calcareous geological environment. In this settlement, archaeological artefacts were also exposed to intensive leaching, due to the location of the site at a stratification joint between Jurassic limestones and Cretaceous marl-limestone (Binder et al., 1993). This site, situated in the south-east of France near the Italian border (Castellar, France), revealed archaeological remains from the Epipaleolithic to the Middle Ages (Binder et al., 1993). Thirteen samples dating from the Early Neolithic period (Impressa ware, 5720 to 5470 BCE; Binder et al., 2017) were selected for analysis. Pottery from this period was recovered in high amounts and is made of three main fabrics: granitoid, glauconitic and mixed granitoid and glauconitic earths (Binder \& Sénépart, 2010; Gabriele, 2014, pp. 223-225). Due to the heterogeneity and complexity of mixed earths, only granitoids and glauconitic potsherds were sampled for the present study. The site of Cuciurpula was selected because of its acidic sediment, unfavourable to microorganism activity (DeLaune et al., 1981; Drieu et al., 2018; Moucawi et al., 1981). Twelve potsherds were sampled from this open-air site dating from the end of the Bronze Age to the first half of the Iron Age and situated in the mountainous region of central south Corsica (Serra-di-Scopamena and Sorbollano, France; Peche-Quilichini et al., 2015). In-depth analysis of the ceramic fabric has not yet been carried out but most of the pottery seems to be made of local granitic earth with high quantity of non-plastic inclusions of variable grain size (Peche-Quilichini, 2010). Clairvaux XIV was selected for its wet and anoxic environment, very unfavourable to biochemical degradation of lipids (Den Dooren De Jong et al., 1961; Eglinton et al., 1991). This site is one of a number of settlements surrounding the Lake of Clairvaux (Jura, France) ranging from the Neolithic to 
the Bronze Age (Pétrequin and Pétrequin, 2016a) and is dated to the first half of the 4th millennium BC (Pétrequin, 2016). For the present study, we selected thirteen potsherds, made of marl clay tempered with ground limestone or calcite (Pétrequin and Pétrequin, 2016b).

To limit excessive destruction of archaeological artefacts, a single fragment of pottery (between 2.5 and $4 \mathrm{~g}$ ) was sampled on each ceramic vessel investigated. Unspecific samples (non-refitting sherds, absence of decoration or chrono-cultural markers) were preferentially selected. Each sample was then divided into two subsamples for lipid and mercury intrusion porosimetry analyses.

Lipids extraction and analysis

Sample treatment and analysis were carried out following Evershed et al. (1990) with slight modifications. When visible residues existed on the surface of potsherds, they were sampled using a clean scalpel blade. Following the vast majority of the literature on lipid residue analysis, the surface of the potsherds (around $1 \mathrm{~mm}$ ) was then removed using a clean scalpel blade to eliminate any exogenous lipid. Around $2 \mathrm{~g}$ of ceramic sherd and between 20 and $100 \mu \mathrm{g}$ of visible residue were then crushed with a mortar and pestle and $20 \mu \mathrm{L}$ of internal standard was added for quantitation ( $n$ tetratriacontane, $1 \mathrm{mg} / \mathrm{mL}$ in $n$-hexane). Lipids were extracted with $10 \mathrm{~mL}$ of dichloromethane/methanol (DCM:MeOH; 2:1, v/v) by sonication $(2 \times 15 \mathrm{~min})$. After centrifugation, the supernatant was evaporated to dryness under a gentle stream of nitrogen and dissolved in $500 \mu \mathrm{L}$ of DCM/MeOH to obtain the total lipid extract (TLE). An aliquot of the TLE (100 $\mu \mathrm{L})$ was evaporated to dryness and treated with $50 \mu \mathrm{L}$ of N,O-bis(trimethylsilyl)trifluoroacetamide containing $1 \%$ trimethylchlorosilane (BSTFA; $70^{\circ} \mathrm{C}, 1 \mathrm{~h}$ ). The excess BSTFA was evaporated under nitrogen and the sample recovered in 25 to $2000 \mu \mathrm{L}$ of cyclohexane (depending on the amount of lipid matter preserved) for high temperature gas chromatography analysis (HT GC). $1 \mu \mathrm{L}$ of sample was introduced into an Agilent Technologies 7890A gas chromatograph, via an oncolumn injector. The analysis was performed using a $15 \mathrm{~m} \times 0.32 \mathrm{~mm}$ i.d. fused silica capillary column (DB5-MS, $0.1 \mu \mathrm{L}$ film thickness, Agilent $\mathrm{J} \& \mathrm{~W}$ ), and helium as carrier gas. The temperature programme consisted of an increase from $50^{\circ} \mathrm{C}$ to $100^{\circ} \mathrm{C}$ at $15^{\circ} \mathrm{C} \cdot \mathrm{min}^{-1}$, and then from $100^{\circ} \mathrm{C}$ to $375^{\circ} \mathrm{C}$ at $10^{\circ} \mathrm{C} \cdot \mathrm{min}^{-1}$. Gas-chromatography mass-spectrometry was used to determine the structure of the molecular compounds, in particular to distinguish between molecules originating from the pottery use and modern contaminants. These analyses were performed on a Shimadzu GC 2010 PLUS chromatograph coupled to a Shimadzu QP 2010 ULTRA mass spectrometer. An aliquot of sample $(1 \mu \mathrm{L})$ was injected on a high temperature non-polar column (DB5-HT, $15 \mathrm{~m} \times 0.322 \mathrm{~mm}$ i.d., $0.1 \mu \mathrm{m}$ film thickness, Agilent J\&W) via a splitless injector. The GC temperature programme was as follows: $1 \mathrm{~min}$ isothermal hold at $50^{\circ} \mathrm{C}$ followed by an increase to $100^{\circ} \mathrm{C}$ at $15^{\circ} \mathrm{C} \cdot \mathrm{min}^{-1}$, then to $240^{\circ} \mathrm{C}$ at $10^{\circ} \mathrm{C} \cdot \mathrm{min}^{-1}$ and to $380^{\circ} \mathrm{C} \cdot \mathrm{min}^{-1}$ and a final isothermal hold for $7 \mathrm{~min}$. The GC-MS interface temperature was maintained at $300^{\circ} \mathrm{C}$. The mass spectrometer was used in electron ionization mode (El, $70 \mathrm{eV}$ ) and mass spectra were acquired over the range $m / z$ 50-950. 
The lipid concentration was calculated by summing the area of all the peaks and comparing it with the area of the internal standard peak. Modern contaminants, such as phthalates (easily identified by the characteristic $m / z 149$ fragment), were excluded from the overall calculation.

This study is part of a wider project of lipid analysis, in which large sets of samples were analysed for each site (Drieu et al., 2018, submitted). For the present study a subset of samples was selected from each of these assemblages to represent the complete range of lipid preservation inside the ceramic walls at each site: the samples with the best preservation of lipids of each site were selected and compared with samples with medium and very low preservation (Table 1). Potsherds from Clairvaux XIV and Cuciurpula originate from a large diversity of ceramic types: cooking pots, serving and storing vessels. The functional study of the pots, based on their content, shape and traces of use have been published elsewhere (Drieu et al., 2018, submitted). Most of the samples from the site of Pendimoun originate from pots of unknown function, especially because it was not possible to reconstruct the form, and they did not display any traces of use (carbonised residues, traces of soot, etc.).

Table 1: List of samples analysed during the study and lipid yield. * two distinct residues removed from the internal and external surfaces of the pot.

\section{Mercury Intrusion Porosimetry}

Mercury intrusion porosimetry analyses were performed using microporosimeter Autopore IV (Micromeritics). The pressure range of the technique was from sub ambient up to $400 \mathrm{MPa}$, in order to cover a pore diameter range from approximately $360 \mu \mathrm{mm}$ to $3 \mathrm{~nm}$. Archaeological samples were broken into fragments having a small volume between 0.5 and $1 \mathrm{~cm}^{3}(0.30$ to $1.75 \mathrm{~g})$, dried overnight in an oven at $45^{\circ} \mathrm{C}$ and introduced alone or in pairs in the analysis cell. A contact angle of $130^{\circ}$ was used for the calculation of the entrance diameter of pores, a value already used for mercury intrusion porosimetry on archaeological samples (Sanders, 1973).

Considering equation (1) where $P$ is the apply pressure; $\gamma$ is the surface tension of the liquid (mercury); $\theta$ is the contact angle between the liquid and the substrate; we can determine $r$, which is the radius of the pores. $r=(-2 \gamma \cos \theta) / P(1)$ This method of characterisation is often used to study the porosity of different types of materials. However, some assumptions need to be considered before discussing the results, such as the aging of the samples, the presence of mineral post-deposits, but also the influences of the pressure on the microstructure, the presence of residual air or humidity into the pores, the use of a cylindrical pore model, etc. (as well explained by A.J. Klemm [2009]). In this study, the preparation of the samples was designed to remove most of the remaining humidity without inducing any damage in the microstructure, by gently drying the samples. The analytical conditions were tested on modern pieces of ceramics in order to rule out the risk of damages due to the pressure. The presence of visible carbonated deposits on some sherds from the site of Pendimoun is not correlated with a reduced porosity, suggesting that they have limited impact on the post-depositional evolution of the 
porosity, contrarily to was stated in the literature (Bronitsky, 1986, pp. 228; Rice, 1987, pp. 353). Finally, these analyses are semi-quantitative due to the use of the cylindrical pore model and the presence of potential residual air or humidity. However, they provide useful comparative results because they were carried out on similar ceramic materials and in the exact same analytical conditions.

It is noteworthy to emphasize that this protocol does not specifically measure the porosity of the internal surface of the pot. This is because mercury not only enters the samples through the pores of the internal and external surface of the pot, but also enters through the fractured edges. The effect of surfaces treatments, such as burnishing and the application of a slip is thus not measured. As these treatments heterogeneously affect the surface properties of the pottery, we think that a specific research project should be entirely dedicated to the study of the influence of the surface properties of the samples. Consequently, as a first approach of the topic, we decided to restrict the scope of this paper to the study of the influence of the core properties (microstructure) of the ceramics.

To evaluate the ability of microorganisms to penetrate the pottery walls, the data of Total Intrusion Volume were subdivided for each sample. Two types of pores were distinguished based on their diameter: pores of diameter larger than $1 \mu \mathrm{m}$, accessible to microorganisms and pores with smaller diameters («small pores»), where microorganisms cannot penetrate due to their size (generally in the range of the micrometer; Davis et al., 1990, p. 21).

\section{RESULTS}

Porosity analysis

Figure 1 details the results obtained on the pore distributions of the samples. The percentage of overall porosity ranges from 14 to $36 \%$ of the volume of the sherd, and the percentage of the total intrusion volume relative to «small pores» (diameters $<1 \mu \mathrm{m}$ ) ranges from 23 to $78 \%$ of the overall porosity (Table 2).

The samples from Pendimoun are distributed in three different porosity groups (Table 2). Samples from the first group (AP1; LD10700a, LD10702a, LD10703a, LD10716a, LD10718a, LD10720a and LD10723) are characterised by:

- an overall porosity between 22 and $25 \%$,

- between 48 and $67 \%$ of pores having a diameter $<1 \mu \mathrm{m}$ («small pores»),

- three main types of pores having a diameter around $10 \mu \mathrm{m}$, around $4 \mu \mathrm{m}$ and between 0.03 and $0.15 \mu \mathrm{m}$ (Figure 1a),

- less than $7 \mu \mathrm{g} \cdot \mathrm{g}^{-1}$ of lipids preserved.

A second group (AP2; LD10711, LD10724, and LD10731) which included three samples made of granitoid paste with:

- much smaller overall porosity, between 16 and 19\%, 
- a smaller quantity of «small pores» having a diameter $<1 \mu \mathrm{m}$ (44 to $45 \%)$,

- one main pore type with a diameter between 0.5 and $4 \mu \mathrm{m}$ (Figure $1 \mathrm{~b}$ ),

- between 1.2 and $34.1 \mu \mathrm{g} . \mathrm{g}^{-1}$ of lipids preserved.

The third group (AP3; LD10710, LD10713, and LD10714; Figure 1c) comprised samples with:

- a small percentage of overall porosity (14 to $20 \%$ ),

- between 23 to $40 \%$ of «small pores» having a diameter $<1 \mu \mathrm{m}$,

- two main types of pores having a diameter around $4 \mu \mathrm{m}$ and around $10 \mu \mathrm{m}$,

- less than $6.6 \mu \mathrm{g} \cdot \mathrm{g}^{-1}$ of lipids preserved.

Figure 1: Differential distribution curves measured by mercury intrusion porosimetry for the archaeological potsherds. a) Group AP1; b) Group AP2; c) Group AP3; d) Group Cuci1; e) Group Cuci2; f) Group Cuci3; g) Group Cl1; h) Group Cl2. Dotted lines indicate the main types of pores discussed in the text.

The percentage of overall porosity is more homogeneous for the samples from Cuciurpula (21.8 to 28.7\%). Three groups of samples can nonetheless be distinguished based on the distribution of the pore diameters (Figure 1d, e, f). The first group (Cuci1; LD10659, LD10665, and MR2707) is defined by samples having:

- between 49 and $45 \%$ of «small pores» with diameters $<1 \mu \mathrm{m}$

- two main types of pores with diameter of around $10 \mu \mathrm{m}$ and $4 \mu \mathrm{m}$, and a smaller number of pores between 0.1 and $1 \mu \mathrm{m}$ (Figure 1d)

- low preservation of lipids ( 0.94 to $15.1 \mu \mathrm{g} . \mathrm{g}^{-1}$ of lipids).

The second group (Cuci2; MR2696, MR2698, MR2711, and MR2717) is characterised by:

- a percentage of «small pores» higher than the group Cuci1 (55 to $57 \%$ )

- three main types of pores with diameters close to $10 \mu \mathrm{m}, 4 \mu \mathrm{m}$ and between 0.01 and $0.1 \mu \mathrm{m}$ (Figure 1e).

- overall low preservation of lipids except one sample that yielded $316.4 \mu \mathrm{g} . \mathrm{g}^{-1}$ of lipids. A third group (Cuci3; LD10656, LD10667, LD10676, MR2699 and MR2701) includes samples characterised by:

- between 46 and $51 \%$ of «small pores» with diameters $<1 \mu \mathrm{m}$

- homogeneous porosity profile without clear peaks (Figure 1f)

- diverse preservation of lipids: two samples yielded respectively 0.2 and $25.0 \mu \mathrm{g} . \mathrm{g}^{-1}$ while the remaining three preserved between 153.3 and $856.2 \mu \mathrm{g} . \mathrm{g}^{-1}$ of lipids.

Samples from Clairvaux XIV were divided in two groups, mainly defined by their percentage of porosity (Figure 1g, h). The first group (Cl1; LD10100, LD10101, LD10103, LD10114, LD10126, and LD10133) comprised samples having:

- overall porosity between 25 and 36\%

- less than $65 \%$ of «small pores»

- two main types of pores with diameters between 6 and $200 \mu \mathrm{m}$ and between 0.02 and $1 \mu \mathrm{m}$ (Figure 1g).

- less than $22 \mu \mathrm{g} \cdot \mathrm{g}^{-1}$ of lipids preserved. 
The second group is composed of the seven samples (CI2; LD10104, LD10113, LD10117, LD10125, LD10129, LD10130, and LD10131) displaying:

- overall porosity between 23 and 30\%

- large quantity of «small pores» (more than 65\%).

- one main type of pores with a diameter between 0.02 and $1 \mu \mathrm{m}$ (Figure $1 \mathrm{~h}$ )

- excellent preservation of lipids (between 95.1 and $901.9 \mu \mathrm{g} . \mathrm{g}^{-1}$, except for LD10104, yielding $3.5 \mu \mathrm{g} \cdot \mathrm{g}^{-1}$ of lipids.

Table 2: Table summarising the results obtained by lipid and mercury intrusion porosimetry analyses for all groups analysed.

Comparison between lipids preservation and porosity

Figure 2: Lipid concentration (TLE, $\mu \mathrm{g} \cdot \mathrm{g}^{-1}$ ) versus overall porosity (a) and «small pores» (diameters $<1$ $\mu \mathrm{m})(\mathrm{b})$.

All the samples preserving lipids have specific porosity values (between 18 and $30 \%$ of overall porosity and 43 and $78 \%$ of «small pores» of diameters $<1 \mu \mathrm{m}$; Figure 2 ), potentially suggesting a range of \% overall porosity and \% of pores of «small pores» (diameters $<1 \mu \mathrm{m}$ ) that favours the preservation of the lipids absorbed into the ceramic matrix.

Particularly, the quantity of «small pores» (diameters $<1 \mu \mathrm{m}$ ) seems to be related to lipid preservation (Figure 3 ). This relationship is notably seen for extreme cases: for example only one of the eight samples displaying less than $45 \%$ of «small pores» with diameters $<1 \mu \mathrm{m}$ yielded more than $20 \mu \mathrm{g} \cdot \mathrm{g}^{-1}$ of lipids (Figure $2 \mathrm{~b}$ ). On the contrary, among the six samples with more than $70 \%$ of "small pores» of diameter $<1 \mu \mathrm{m}$, five preserved lipids (Figure $2 \mathrm{~b}$ ). The samples having significant percentage of overall porosity (more than 26\%; LD10100, LD10103, LD10114, LD10133, LD10659, MR2707, LD10665, LD10126), seem to better preserve lipids when their porosity is mostly made up of «small pores» (more than $65 \%$ of pores of diameter $<1 \mu \mathrm{m}$ ). The near absence of lipids in some samples which have a large quantity of «small pores» (LD10104, LD10700, LD10702, LD10703, LD10716, LD10718, LD10720, LD10723, MR2698, MR2699, MR2711, MR2717) could be related to other parameters such as chemical degradation or specific use of the vessels for non-fatty substances. This latter hypothesis is confirmed for 4 samples from Cuciurpula (MR2698, MR2699, MR2711, and MR2717) bearing visible surface residues that yielded very low amounts of lipids (between 3 and $84 \mu \mathrm{g} \cdot \mathrm{g}^{-1}$, when other visible residues at the site contain several hundred $\mu \mathrm{g} . \mathrm{g}^{-1}$; Table 1 and Drieu et al., 2018).

Figure 3: Degree of preservation of lipids depending on «small pores» $<1 \mu \mathrm{m}$. Samples with TLE $>20$ $\mu \mathrm{g} . \mathrm{g}^{-1}$ are considered as well preserved and those with TLE $<20 \mu \mathrm{g} . \mathrm{g}^{-1}$ are considered as badly preserved. The percentage indicated corresponds to the $\%$ of well-preserved samples for each category of size distribution of «small pores» $<1 \mu \mathrm{m}$. 
The impact of "small pores» is mainly seen in potsherds from Pendimoun and Clairvaux XIV (Figure

361

362

363

364

365

366

367

368

369

370

371

372

373

374

375

376

377

378

379

380

381

382

383

384

385

386

387

388

389

390

391

392

393

394

395

396

397

398

399

400

401

402 $2 \mathrm{~b})$, as they display extreme cases of porosity: a very low quantity of «small pores» in Pendimoun and a very high quantity in Clairvaux XIV. At Pendimoun, samples with less than $40 \%$ of «small pores» (LD10713 and LD10714) did not preserved any lipids, while the only sample yielding more than 20 $\mu \mathrm{g} \cdot \mathrm{g}^{-1}$ of lipids displays such pores, even in small quantities (LD10731, $44 \%$ of pores $<1 \mu \mathrm{m}$ ). Samples from Clairvaux XIV with both a high quantity of «small pores» and absence of pores of large diameter (more than $10 \mu \mathrm{m}$; Group $\mathrm{Cl}$ ) seem to preserve the highest quantity of lipids: $85 \%$ of samples yielding more than $20 \mu \mathrm{g} \cdot \mathrm{g}^{-1}$ are also characterised by more than $65 \%$ of «small pores» with diameters smaller than $1 \mu \mathrm{m}$. At Cuciurpula, the porosity range seems to have a lesser impact on the preservation of lipids into pottery walls, as lipids are better preserved inside samples with a very homogenous distribution of pores (Group Cuci3).

\section{DISCUSSION}

Diversity of the porosity pattern and making of the pottery

Pottery from the three sites investigated presents various patterns of porosity (Figure 4): sherds from Clairvaux XIV are the most porous (mean value of overall porosity of $28 \%$ ) with the highest level of «small pores» < $1 \mu \mathrm{m}$ (mean value of «small pores» of 66.\%) while the opposite if observed for the site of Pendimoun (mean value of overall porosity of $25 \%$; mean value of «small pores» of $50 . \%$ ). The site of Cuciurpula presents intermediate values (mean value of overall porosity of $21 \%$; mean value of «small pores» of 66\%). This diversity reflects different manufacturing chaînes opératoires between sites: differences in terms of the nature of the clay, quantity, nature and granulometry of non-plastic inclusions, intensity of handling, and firing conditions (Bronitsky, 1986, p. 226; Rice, 1987, p. 351; Rye, 1981, pp. 40 and 122; Shepard, 1956, p. 126; Skibo, 2013, p. 40). For example, at Pendimoun, the small percentage of overall porosity of some samples (groups AP2 and AP3) and the absence of very small pores (less than $0.1 \mu \mathrm{m}$ ) are to be compared with petrographic information. Sherds investigated are all made of granitoid earth and comprised very large quantities of non-plastic inclusions and a very small amount of clay matrix (Binder \& Sénépart, 2010). This specificity of the ceramic paste could explain the absence of very small pores, that are probably related to clay structures and cannot exist if no clay fine fraction is present. At Clairvaux, the porosity seems to be related to the level of savoir-faire (Pétrequin and Pétrequin, 2016b): the best made ceramics generally have low overall porosity and high amount of «small pores».

Figure 4: Overall porosity versus «small pores» (diameter $<1 \mu \mathrm{m}$ ) depending on the sites investigated.

Relationship between porosity and preservation of lipids 
Given the diversity of environmental contexts considered in this study, the diameter of the pores appears to impact different types of lipids degradation processes.

First, our results confirm that the presence of «small pores» limits the degradation of lipids by

408

409

410

411

412

413

414

415

416

417

418

419

420

421

422

423

424

425

426

427

428

429

430

431

432

433

434

435

436

437

438

439

440

441

442

443

444

445

446 microorganisms, as supposed in the literature. Generally larger than $1 \mu \mathrm{m}$, (Davis et al. 1990, p. 21) most of bacteria and fungi are not able to enter pores smaller than this size. Thus, the lipids within the ceramic matrix are protected from microbial degradation (Evershed, 1993, 2008; Heron et al., 1991; Heron and Evershed, 1993; Matlova et al., 2017; Saboyainsta and Maubois, 2000). This property has been exploited in food science for microfiltration: porous ceramic fabrics with pore diameters under $1.4 \mu \mathrm{m}$ are used as effective milk microfiltration devices, removing up to $99.75 \%$ of microorganisms responsible for the biochemical degradation of milk (Saboyainsta and Maubois, 2000; Trouvé et al., 1991). The impact of porosity on the degradation of lipids by biochemical degradation was probably important at the site of Pendimoun, but limited at Clairvaux XIV and Cuciurpula respectively due to the anoxic context of Clairvaux and the acidic sediments of Cuciurpula (Drieu et al., 2018, submitted) considerably reducing microbial activity.

Other degradation processes therefore need to be considered to explain the impact of porosity on the preservation of lipids at Clairvaux. In this wet environment, reduced transport of water through porosity is more likely to explain good preservation of lipids in «small pores». Following Poiseuille equation, for a laminar flow of water, the smaller the radius of the pore the slower the flow rates through it. In "small pores», the slowing of the water flow probably limits the leaching of absorbed lipids, and possibly reduces hydrolysis. A similar hypothesis has also been suggested to explain the poor preservation of chlorine in Late Neolithic salt moulds (Ard and Weller, 2012). This type of degradation process may have also occurred at Pendimoun. Indeed, despite the limited rainfalls of the Mediterranean climate, this rock shelter is exposed to a significant water flow related to its geological location, as evidenced by the substantial calcium carbonate deposits on the potsherds from the site (Binder et al., 1993). At Cuciurpula, leaching is probably limited as the site is open-air, without rock walls favouring water flow.

The effect of other parameters on lipid degradation in archaeological samples should also be examined in the future.

First, the impact of pottery surface treatment (slipping, burnishing) on the absorption and the degradation of organic matter has never been studied in-depth, to the best of our knowledge (Reber, 2007). However, this type of treatment considerably modifies the surface of the pots by promoting smaller pores at the surface of the walls, probably affecting both the preservation of lipids and the amount absorbed during pottery use (Correa-Ascencio and Evershed, 2013; Reber, 2007). A protocol for coating the edges of potsherds with polymer resin is under development to specifically measure the porosity of the internal surface of the vessels. This investigation will be particularly useful to better understand some samples from Pendimoun that display evidence of deep burnishing (Binder et al., 1993; Binder \& Maggi, 2001), not reflected in the core porosity measured in the present study. Secondly, hydrolysis is not the only chemical reaction responsible for the degradation of lipids in archaeological samples: radical oxidation, photo-oxidation, and reduction also affect the lipid content (Aillaud, 2001; Heron and Evershed, 1993) and porosity has probably no impact on it. 
Finally, the actual use of pottery is a key parameter influencing the amount of lipids absorbed and preserved in archaeological potsherds. The absence of lipids in numerous samples from Pendimoun may not be due to their degradation but to specific use of pottery in this early phase of the Neolithic in the western Mediterranean, to transform cereals or to store water, for example, as suggested by other researchers (Spiteri et al., 2017).

\section{CONCLUSION}

This article has revealed that when potsherds are exposed to normal microbial activity (as at the site of Pendimoun) or to water (at Clairvaux XIV, and to a lesser extent at Pendimoun), the range of porosity inside the pottery walls is of importance for the preservation of lipids. When trapped in "small pores» (less than $1 \mu \mathrm{m}$ of diameter), lipids are protected from microorganisms, but also from leaching. A high abundance of «small pores» of diameter $<1 \mu \mathrm{m}$ in pottery walls favours thus the preservation of lipids in archaeological samples, by reducing biological (microorganism activity), physical (leaching) and possibly chemical (hydrolysis) degradation.

In very specific environments when leaching is limited, and microorganism activity reduced, porosity appears to have a limited impact on the preservation of lipids. The site of Cuciurpula considered in this study meets these criteria, but other types of archaeological contexts, such as arid or frozen environments, should be considered and studied in the future.

These first results need now to be confirmed with new analyses of larger sample sets from a range of environmental contexts (acid and basic soils, arid, frozen and submerged environments). A better understanding of the preservation of lipids in porous ceramic matrices could lead to more selective sampling of pottery in the future, avoiding the destruction of archaeological potsherds unlikely to have preserved lipids. Secondly, mercury intrusion porosimetry can be used as a new tool for functional analysis allowing a better understanding of the process of penetration of organic substances into the porous walls of ceramic vessels and the degradation likely to have occurred. In particular, this technique can be used to understand the use of ceramic vessels yielding small amounts of lipids, such as in the Mediterranean.

\section{ACKNOWLEDGMENTS}

This research was partly funded by a grant from the Agence Nationale de la Recherche for the project 'Western Mediterranean Impressed Wares. An interdisciplinary research on Early Neolithic pottery (6th millennium cal BCE): sourcing, production, uses and transfers' (ANR n¹4CE310009; 2015-2018; dir.: D. Binder). We thank the ICN (Institute of Chemistry of Nice, UMR 7272 UNS - CNRS) where gas chromatography and gas chromatography-mass spectrometry analyses were performed. We are also thankful to Jasmine Lundy for her careful re-reading of this article and to reviewers for their fruitful considerations that helped to improve this article.

\section{REFERENCES}


Adrian De la Fuente, G., Vera, S.D., 2015. Using image analysis software (IAS) for the technological characterization of archaeological ceramics: scope, limitations and perspectives. Chungara Rev. Antropol. Chil. 47, 257-265.

497

Aprile, A., Castellano, G., Eramo, G., 2014. Combining image analysis and modular neural networks for classification of mineral inclusions and pores in archaeological potsherds. J. Archaeol. Sci. 50, 262272. https://doi.org/10.1016/j.jas.2014.07.017

502

503

504

505

506

507

508

509

510

511

512

513

514

515

516

517

518

519

520

521

522

523

524

525

Aillaud, S., 2001. Field and laboratory studies of diagenetic reactions affecting lipid residues absorbed in unglazed archaeological pottery vessels. PhD thesis, University of Bristol.

Ard, V., Weller, O., 2012. Les vases de «type Champ-Durand»: témoins d'une exploitation du sel au Néolithique récent dans le Marais poitevin, in: Joussaume, R. (Ed.), L'enceinte Néolithique de ChampDurand à Nieul-Sur-l'Autise (Vendée). Assoc. des Publ. Chauvinoises, Chauvigny, pp. 309-333.

Binder, D., Brochier, J.-E., Duday, H., Helmer, D., Marinval, P., Thiebault, S., Wattez, J., 1993. L'abri Pendimoun à Castellar (Alpes-Maritimes). Nouvelles données sur le complexe culturel de la céramique imprimée méditerranéenne dans son contexte stratigraphique. Gall. Préhistoire 35, 177251.

Binder, D., Lanos, P., Angeli, L., Gomart, L., Guilaine, J., Manen, C., Maggi, R., Muntoni, I.M., Panelli, C., Radi, G., Tozzi, C., Arobba, D., Battentier, J., Brandaglia, M., Bouby, L., Briois, F., Carré, A., Delhon, C., Gourichon, L., Marinval, P., Nisbet, R., Rossi, S., Rowley-Conwy, P., Thiebault, S., 2017. Modelling the earliest north-western dispersal of Mediterranean Impressed Wares: new dates and Bayesian chronological model. Documenta Praehistorica 44, 54-77. http://dx.doi.org/10.4312/dp.44.4

Binder, D., Maggi, R., 2001. Le Néolithique ancien de l’arc liguro-provençal. Bull. Soc. Préhist. Fr. 98, 411-422.

Binder, D., Sénépart, I., 2010. La séquence de l'Impresso-Cardial de l'abri Pendimoun et l'évolution des assemblages céramiques en Provence, in: Manen, C., Convertini, F., Binder, D., Sénépart, I. (Eds.), Premières Sociétés Paysannes de Méditerranée Occidentale : Structures Des Productions Céramiques. Séance de La Société Préhistorique Française, Toulouse, 11-12 Mai 2007. Soc. Préhist. Fr., Paris, pp. 149-167. 
Bronitsky, G., 1986. The use of materials science techniques in the study of pottery construction and use. Adv. Archaeol. Method Theory 9, 209-276. https://doi.org/10.1016/B978-0-12-003109-2.50008$\underline{8}$

Carvalho, A.P., Vaz, M.F., Pires, J., Samora, M.J., 2006. Characterisation of ceramic pastes of Portuguese ancient tiles. Mater. Sci. Forum 514-516, 1648-1652.

https://doi.org/10.4028/www.scientific.net/MSF.514-516.1648

Charters, S., Evershed, R.P., Quye, A., Blinkhorn, P.W., Reeves, V., 1997. Simulation experiments for determining the use of ancient pottery vessels: the behaviour of epicuticular leaf wax during boiling of a leafy vegetable. J. Archaeol. Sci. 24, 1-7. https://doi.org/10.1006/jasc.1995.0091

Correa-Ascencio, M., Evershed, R.P., 2013. High throughput screening of organic residues in archaeological potsherds using direct acidified methanol extraction. Anal. Methods 6, 1330-1340. https://doi.org/10.1039/c3ay41678j

Craig, O.E., Steele, V.J., Fischer, A., Hartz, S., Andersen, S.H., Donohoe, P., Glykou, A., Saul, H., Jones, D.M., Koch, E., Heron, C.P., 2011. Ancient lipids reveal continuity in culinary practices across the transition to agriculture in Northern Europe. Proc. Natl. Acad. Sci. U. S. A. 108 (44), 17910-17915. https://doi.org/10.1073/pnas.1107202108

Davis, B.D., Dulbecco, R., Eisen H.N., Ginsberg, H.S., 1990. Microbiology, 4th ed. Lippincott, Philadelphia.

Debono Spiteri, C., Gillis, R.E., Roffet-Salque, M., Castells Navarro, L., Guilaine, J., Manen, C., Muntoni, I.M., Segui, M.S., Urem-Kotsou, D., Whelton, H.L., Craig, O.E., Vigne, J.-D., Evershed, R.P., 2016. Regional asynchronicity in dairy production and processing in early farming communities of the northern Mediterranean. Proc. Natl. Acad. Sci. 113 (48), 13594-13599.

https://doi.org/10.1073/pnas.1607810113

DeLaune, R., Reddy, C., Patrick, W., 1981. Organic matter decomposition in soil as influenced by pH and redox conditions. Soil Biol. Biochem. 13 (6), 533-534.

Den Dooren De Jong, I., Dauvillier, M.M., Roman, W., 1961. On the formation of adipocere from fats. Antonie Van Leeuwenhoek 27 (1), 337-361. 
Drieu, L., Mirabaud, S., Roffet-Salque, M., Blasco, T., Pétrequin, P., Pétrequin, A.-M., Evershed, R.P., Regert, M., submitted. Defining pottery use and exploitation of natural products at Clairvaux XIV during the Middle Neolithic. Settling watery landscapes in Europe: archaeology of pile-settlements of Neolithic-Bronze Age, Themes in Contemp. Archaeol.

Drieu, L., Peche-Quilichini, K., Lachenal, T., Regert, M., 2018. Domestic activities and pottery use in the Iron Age Corsican settlement of Cuciurpula revealed by organic residue analysis. J. Archaeol. Sci. Rep. 19, 213-223. https://doi.org/10.1016/i.jasrep.2018.02.032

Eglinton, G., Logan, G.A., Ambler, R., Boon, J., Perizonius, W., 1991. Molecular preservation. Philos. Trans. R. Soc. B Biol. Sci. 333 (1268), 315-328. https://doi.org/10.1098/rstb.1991.0081

Evershed, R.P., 2008. Organic residue analysis in archaeology: the archaeological biomarker revolution. Archaeometry 50 (6), 895-924. https://doi.org/10.1111/j.1475-4754.2008.00446.x

Evershed, R.P., 1993. Biomolecular archaeology and lipids. World Archaeol. 25 (1), 74-93. https://doi.org/10.1080/00438243.1993.9980229

Evershed, R.P., Charters, S., Quye, A., 1995. Interpreting lipid residues in archaeological ceramics: Preliminary results from laboratory simulations of vessel use and burial. Mater. Res. Symp. Proc. 352 (85), 85-95. https://doi.org/10.1557/PROC-352-85

Evershed, R.P., Stott, Evershed, R.P., Copley, M.S., Dickson, L., Hansel, F.A., 2008a. Experimental evidence for the processing of marine animal products and other commodities containing polyunsaturated fatty acids in pottery vessels. Archaeometry 50 (1), 101-113. https://doi.org/10.1111/j.1475-4754.2007.00368.x

Evershed, R.P., Heron, C., Goad, L.J., 1990. Analysis of organic residues of archaeological origin by high-temperature gas chromatography and gas chromatography-mass spectrometry. Analyst 115 , 1339-1342. https://doi.org/10.1039/AN9901501339

Evershed, R.P., Payne, S., Sherratt, A.G., Copley, M.S., Coolidge, J., Urem-Kotsu, D., Kotsakis, K., Özdoğan, M., Özdoğan, A.E., Nieuwenhuyse, O., Akkermans, P., Bailey, D., Andeescu, R.R., Campbell, S., Farid, S., Hodder, I., Yalman, N., Özbaşaran, M., Biçakci, E., Garfinkel, Y., Levy, T., Burton, M.M., 2008b. Earliest date for milk use in the Near East and southeastern Europe linked to cattle herding. Nature 455, 528-531. https://doi.org/10.1038/nature07180 

Neolithic societies of western Mediterranean (Sardinia, Italy, 4500-4000 cal BC) revealed through an integrated morphometric, use-wear, biomolecular and isotopic approach. J. Archaeol. Sci. 93, 110128. https://doi.org/10.1016/i.jas.2018.03.005

631

Gabriele, M., 2014. La circolazione delle ceramiche del Neolitico nel medio e alto Tirreno e nell'area ligure-provenzale. Studi di provenienza. PhD Thesis Università di Pisa, Université de Nice SophiaAntipolis.

Giesche, H., 2006. Mercury porosimetry: a general (practical) overview. Part. Part. Syst. Charact. 23 manufacture and the introduction of farming to Southern Europe. Antiquity 91 (360), 1501-1514. https://doi.org/10.15184/aqy.2017.187

Heron, C., Evershed, R.P., 1993. The analysis of organic residues and the study of pottery use. Archaeol. Method Theory 5, 247-284.

Heron, C., Evershed, R.P., Goad, L.J., 1991. Effects of migration of soil lipids on organic residues associated with buried potsherds. J. Archaeol. Sci. 18, 641-659. https://doi.org/10.1016/03054403(91)90027-M

Klemm, A.J., 2009. Microstructural characterisation of porous construction materials - major challenges. Comput. Method Exp. Mater. Charact. IV 64, 395-406. and Belarus. Old Potters Alm. 21, 2-12. 
Maniatis, Y., Tsirtsoni, Z., 2002. Characterization of a black residue in a decorated Neolithic pot from Dikili Tash, Greece: an unexpected result. Archaeometry 44 (2), 229-239.

https://doi.org/10.1111/1475-4754.t01-1-00055

Matlova, V., Roffet-Salque, M., Pavlu, I., Kyselka, J., Sedlarova, I., Filip, V., Evershed, R.P., 2017.

Defining pottery use and animal management at the Neolithic site of Bylany (Czech Republic). J.

Archaeol. Sci. Rep. 14, 262-274. https://doi.org/10.1016/i.jasrep.2017.05.028

Morariu, V., Bogdan, M., Ardelean, I., 1977. Ancient pottery: its pore structure. Archaeometry 19 (2), 187-192. https://doi.org/10.1111/j.1475-4754.1977.tb00197.x

Moraru, L., Szendrei, F., 2010. Ancient pottery analysis using SEM image processing. Eur. J. Sci. Theol. $6(2), 69-78$.

Moucawi, J., Fustec, E., Jambu, P., Jacquesy, R., 1981. Decomposition of lipids in soils: free and esterified fatty acids, alcohols and ketones. Soil Biol. Biochem. 13 (6), 461-468.

https://doi.org/10.1016/0038-0717(81)90035-3

Namdar, D., Stacey, R.J., Simpson, S.J., 2009. First results on thermally induced porosity in chlorite cooking vessels from Merv (Turkmenistan) and implications for the formation and preservation of archaeological lipid residues. J. Archaeol. Sci. 36, 2507-2516.

https://doi.org/10.1016/i.jas.2009.07.003

Pecci, A., Degl'Innocenti, E., Giorgi, G., Ontiveros, M.Á.C., Cantini, F., Potrony, E.S., Alós, C., Miriello, D., 2015. Organic residue analysis of experimental, medieval, and post-medieval glazed ceramics. Archaeol. Anthropol. Sci. 8 (4), 879-890. https://doi.org/10.1007/s12520-015-0262-3

Pecci, A., Gabrieli, R.S., Inserra, F., Cau, M.A., Waksman, S.Y., 2016. Preliminary results of the organic residue analysis of 13th century cooking wares from a household in Frankish Paphos (Cyprus). STAR : Sci. Technol. Archaeol. Res. 1 (2), 99-105. https://doi.org/10.1080/20548923.2016.1183960

Peche-Quilichini, K., 2010. Le vase de fondation zoomorphe du Premier Âge du fer de Cuciurpula (Serra-di-Scopamene/Sorbollano, Corse-du-Sud). Bull. Société Préhistorique Fr. 107 (2), 371-381. 
Peche-Quilichini, K., Delvaux, S., Lachenal, T., Grevey, A.-L., Amici, S., de Lanfranchi, F., Bartoloni, G., Milletti, M., Bergerot, L., Mottolese, C., 2015. L'espace domestique au Bronze final et au premier âge du Fer dans le sud de la Corse. Trab. Prehist. 72 (2), 259-281. https://doi.org/10.3989/tp.2015.12154

Pétrequin, P., 2016. Le "Néolithique Moyen Bourguignon" (N.M.B.) et la problématique de recherche, in: Pétrequin, P., Pétrequin, A.-M. (Eds.), Clairvaux et Le "Néolithique Moyen Bourguignon." Presses univ. de Franche-Comté et CRAVA, Besançon, pp. 11-19.

Pétrequin, P., Pétrequin, A.-M., 2016a. Evaluation archéologique et découverte des villages Néolithique moyen II du Grand Lac de Clairvaux, in: Pétrequin, P., Pétrequin, A.-M. (Eds.), Clairvaux et Le "Néolithique Moyen Bourguignon." Presses univ. de Franche-Comté et CRAVA, Besançon, pp. 2349.

Pétrequin, P., Pétrequin, A.-M., 2016b. Techniques céramiques : dégraissants, outillages, montage, cuisson et styles, in: Pétrequin, P., Pétrequin, A.-M. (Eds.), Clairvaux et Le "Néolithique Moyen Bourguignon." Presses univ. de Franche-Comté et CRAVA, Besançon.

Reber, E., 2007. The well-tempered pottery analysis: residue and typological analysis of potsherds from the Lower Mississippi Valley, in: Barnard, H., Eerkens, J.W. (Eds.), Theory and Practice of Archaeological Residue Analysis. Archaeopress, Oxford, pp. 148-160.

Reedy, C.L., Anderson, J., Reedy, T.J., Liu, Y., 2014. Image Analysis in Quantitative Particle Studies of Archaeological Ceramic Thin Sections. Adv. Archaeol. Pract. 2(4), 252-268.

https://doi.org/10.7183/2326-3768.2.4.252

Regert, M., 2011. Analytical strategies for discriminating archeological fatty substances from animal origin. Mass Spectrom. Rev. 30 (2), 177-220. https://doi.org/10.1002/mas.20271

Rice, P.M., 1987. Pottery analysis, a sourcebook. The Univ. of Chicago Press, Chicago and London.

Rye, O. S. (1981). Pottery technology: principles and reconstruction. Taraxacum, Washington DC. Saboyainsta, L.V., Maubois, J.-L., 2000. Current developments of microfiltration technology in the dairy industry. Le lait 80 (6), 541-553. https://doi.org/10.1051/lait:2000144 
Salque, M., Bogucki, P.I., Pyzel, J., Sobkowiak-Tabaka, I., Grygiel, R., Szmyt, M., Evershed, R.P., 2013. Earliest evidence for cheese making in the sixth millennium BC in northern Europe. Nature 493, 522525. https://doi.org/10.1038/nature11698

Sanders, H.P., 1973. Pore-size distribution determinations in Neolithic, Iron Age, Roman and other pottery. Archaeometry 15 (1), 159-161. https://doi.org/10.1111/j.1475-4754.1973.tb00085.x

Shepard, A.O., 1956. Ceramics for the archaeologist. Carnegie Institution of Washington, Washington, DC.

Skibo, J.M., 2013. Understanding pottery function, Manuals in Archaeological Methods, Theory and Technics. Springer, New York.

Sobott, R., Bente, K., Kittel, M., 2014. Comparative porosity measurements on ceramic materials. Old Potters Alm. 19, 18-25.

Spiteri, C., Muntoni, I.M., Craig, O.E., 2017. Dietary Practices at the Onset of the Neolithic in the Western Mediterranean Revealed Using a Combined Biomarker and Isotopic Approach, in: García Puchol, O., Salazar García, D.C. (Eds.), Times of Neolithic Transition along the Western Mediterranean, Fundamental Issues in Archaeology. Springer, pp. 253-279.

Thér, R., 2016. Identification of pottery-forming techniques using quantitative analysis of the orientation of inclusions and voids in thin sections. Archaeometry 58 (2), 222-238. https://doi.org/10.1111/arcm.12166

Trouvé, E., Maubois, J., Piot, M., Madec, M., Fauquant, J., Rouault, A., Tabard, J., Brinkman, G., 1991. Rétention de différentes espèces microbiennes lors de l'épuration du lait par microfiltration en flux tangentiel. Le lait 71 (1), 1-13. https://doi.org/10.1051/lait:199111

Volzone, C., Zagorodny, N., 2014. Mercury intrusion porosimetry (MIP) study of archaeological pottery from Hualfin Valley, Catamarca, Argentina. Appl. Clay Sci. 91-92, 12-15.

https://doi.org/10.1016/i.clay.2014.02.002

FIGURES 

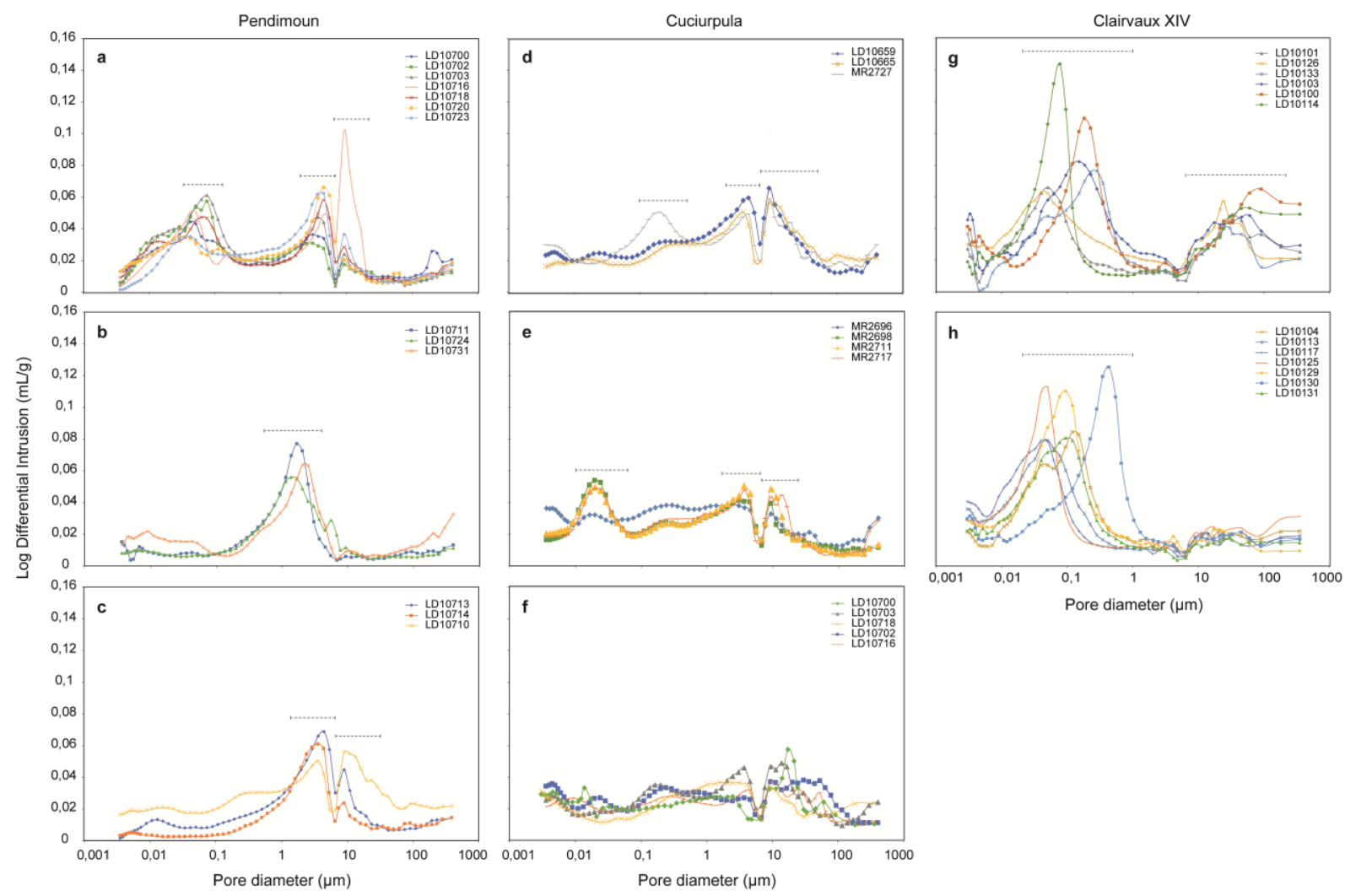

801

Figure 1

803

804 


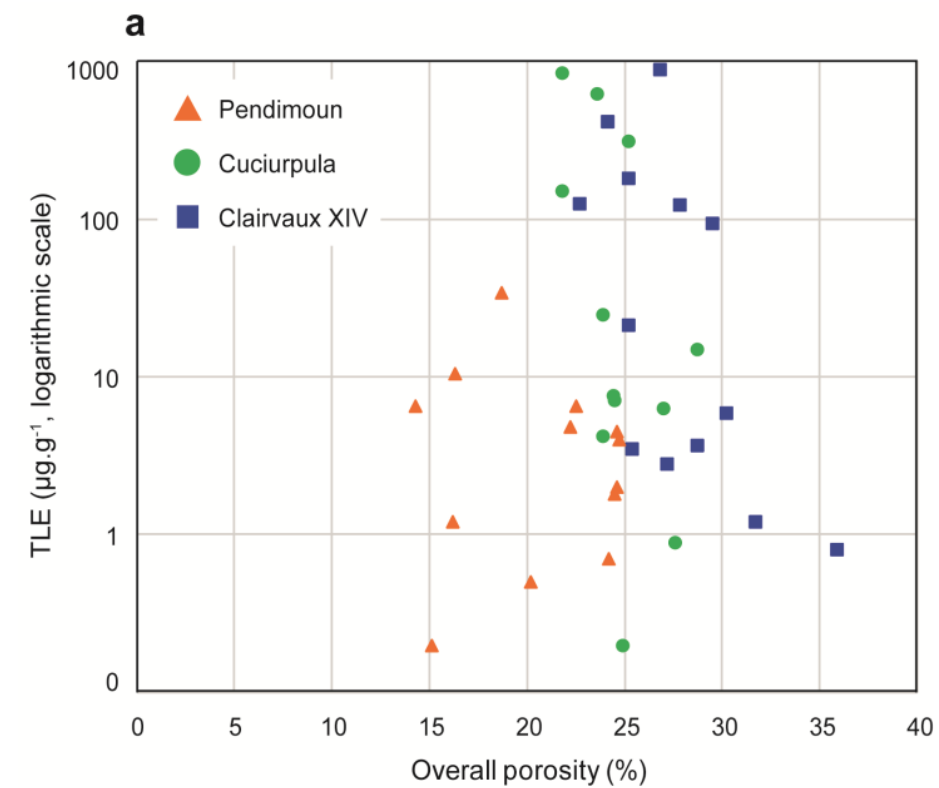

b

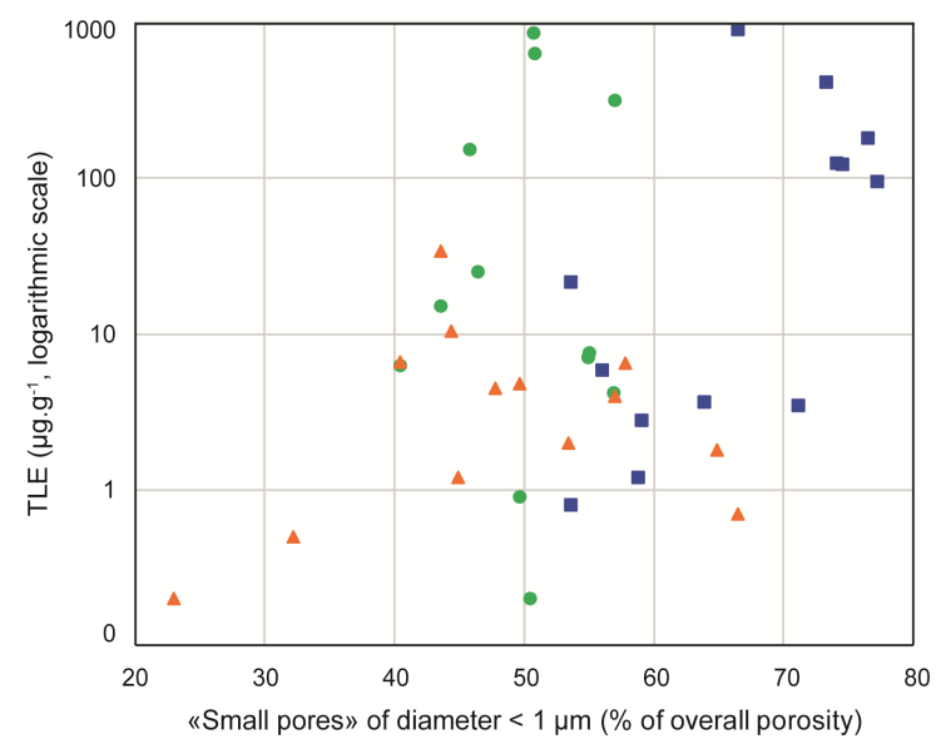

805

806

Figure 2

807

808

809 


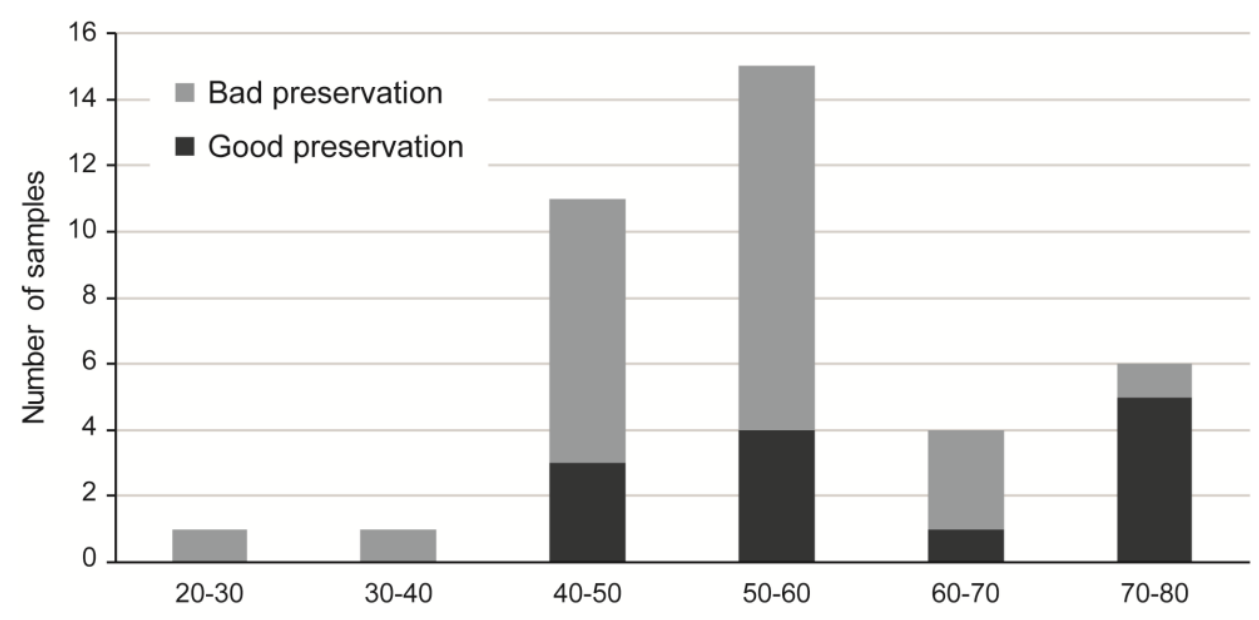

810

811

812

813

814

815

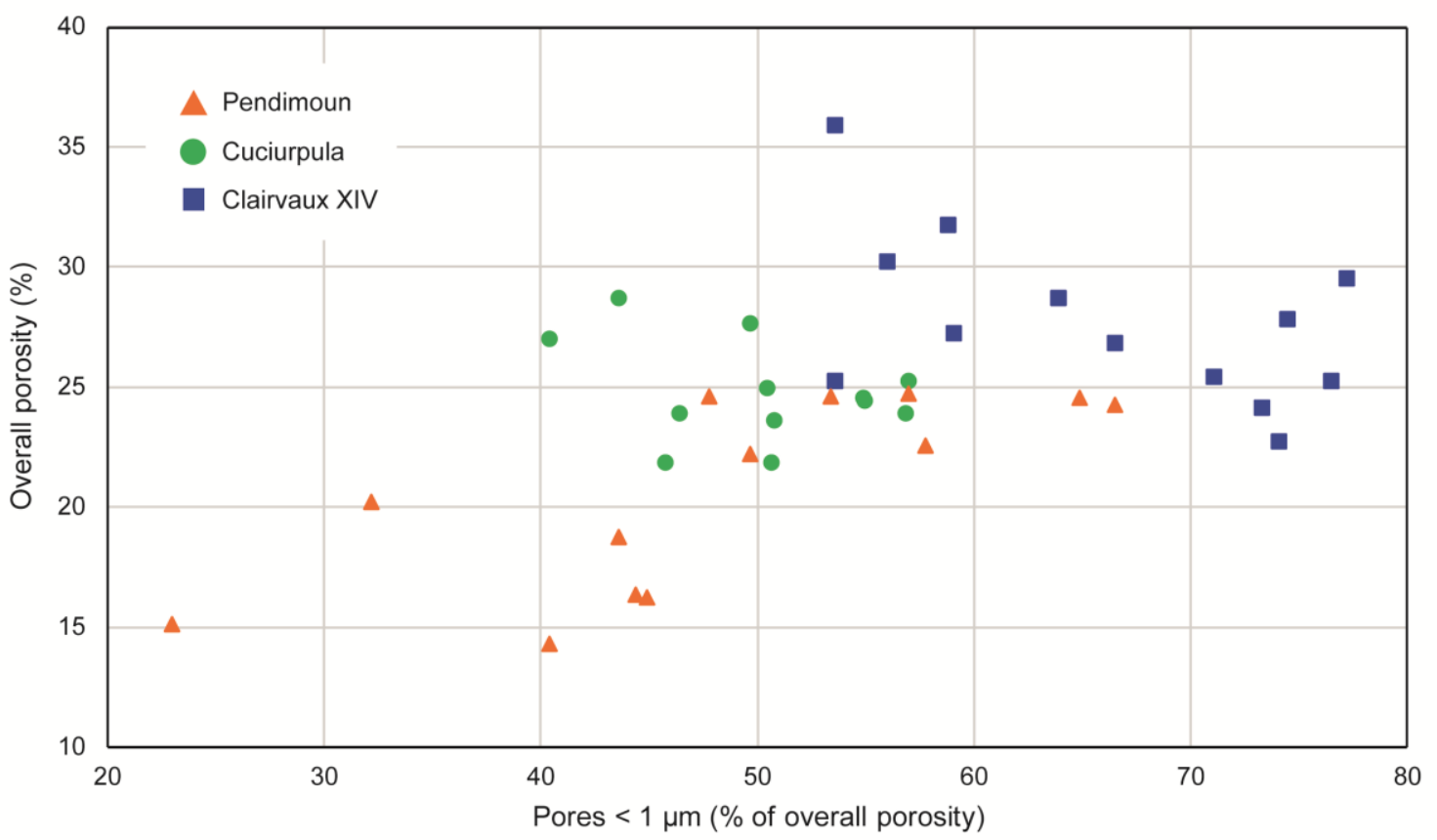

Size distribution of pores $<1 \mu \mathrm{m}$ ( $\%$ of overall porosity)

\section{Figure 3}

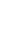

816

817

Figure 4 